\title{
Analisis Pengaruh Rasio Keuangan terhadap Harga Saham pada Bank di Bursa Efek Indonesia
}

\author{
Oleh: \\ Robert Lambey \\ Fakultas Ekonomi dan Bisnis \\ Universitas Sam Ratulangi Manado \\ Email: Robert_lambey@yahoo.com
}

\begin{abstract}
Abstrak
Tujuan penelitian ini mengetahui pengaruh analisis rasio keuangan yaitu $C R$, ROA,DER,dan TATO terhadap Harga Saham pada bank. Dalam hal ini peneliti menggunakan data berupa laporan keuangan Bank yang tercatat di Bursa Efek Indonesia (BEI). Peneliti menggunakan sampel sebanyak 7 Bank yang dipilih secara purposive random sampling, yaitu perusahaan Bank yang terdaftar di BEI periode tahun 20082011. Data laporan keuangan yang digunakan adalah laporan keuangan yang telah dipublikasikan di dalam Indonesia Capital Market Directory (ICMD) 2013. Alat analisis yang digunakan adalah analisis regresi berganda, uji $t$, uji $F$ dan koefisien determinasi yang diuji dengan uji asumsi klasik. Berdasarkan hasil analisis data dapat disimpulkan bahwa variabel ROA dan TATO mempunyai pengaruh yang signifikan terhadap Harga Saham.
\end{abstract}

Kata Kunci: CR,ROA,DER, TATO, Harga Saham.

Abstract

The purpose of this study to know the effect of financial ratio analysis, namely $C R, R O A$, $D E R$, and TATO to the stock price on the bank. In this case the researchers used the data in the form of financial statements of the Bank are listed on the Indonesia Stock Exchange (IDX). Researchers used a sample of 7 Banks are selected by purposive random sampling, the bank company listed on the Stock Exchange in the period 2008-2011. The data used financial statements are the financial statements that have been published in the Indonesian Capital Market Directory (ICMD) 2013. Analytical tool used is multiple regression analysis, $t$ test, $F$ test and coefficient of determination are tested with classical assumption test. Based on the analysis of data it can be concluded that the variables ROA and TATO has a significant effect on stock price.

Keywords: CR, ROA, DER, TATO, Stock Price 


\section{PENDAHULUAN}

Investasi merupakan penanaman modal oleh investor dalam suatu entitas bisnis, yang didalamnya terkandung risiko ketidakpastian, apabila bisnis tersebut dikelola dengan benar oleh manajer maka bisa memberikan keuntungan bagi investor sebagai suatu kompensasi atas investasi yang dilakukannya yang dikenal dengan istilah keuntungan dari investasi atau gain. Salah satu hasil yang diharapkan oleh investor atas investasi yang dilakukannya adalah pembagian dividen sebagai bagian pembagian laba yang terjadi didalam perusahaan atau bisa juga keuntungan yang didapat dari kenaikan harga saham yang dibelinya yang juga dapat meningkatkan kesejahteraan (wealth) bagi investor.

Bagi Setiap investor yang menanamkan uangnya dalam suatu entitas bisnis perusahaan mengharapkan keuntungan atas investasi yang dilakukannya tersebut. Investor perlu juga mempergunakan berbagai pertimbangan untuk menilai jenis perusahaan yang layak untuk diinvestasikan yang dapat memberikan keuntungan yang optimal bagi investor. Sehingga investor dapat membuat langkah-langkah strategis dengan analisis investasi pada perusahaanperusahaan dimana investor tersebut melakukan penanaman modal.

Penanaman modal oleh investor merupakan wujud keinginan untuk mendapatkan pengembalian modal dan pengembangan dana di kemudian hari. Investor melakukan penanaman modal melalui pembelian saham di pasar modal. Pasar modal merupakan wadah alternatif selain bank dan lembaga keuangan non bank bagi para investor untuk melakukan penanaman modal (investasi). Salah satu indikasi bekerjanya pasar modal secara optimal adalah ketersediaan informasi, baik informasi keuangan maupun informasi non keuangan yang bersifat simetris dan dapat diakses oleh semua pihak yang berkepentingan. Informasi tersebut berguna bagi investor sebagai dasar mengadakan penilaian dan analisis investasi yang dilakukannya terhadap perusahaan. Oleh karena itu peranan pasar modal menjadi semakin penting mengingat fungsi pasar modal sebagai tempat bertemunya pihak yang membutuhkan dana, dan pihak yang ingin menanamkan modalnya. (Wiji P dan Hendy F,3:2006)

Penilaian emiten suatu perusahaan didapat dari informasi yang tersedia di pasar modal sehingga masyarakat dapat dengan mudah memperoleh informasi tentang penilaian emiten suatu perusahaan. Salah satu aspek yang dinilai oleh masyarakat dalam investasi adalah kinerja keuangan perusahaan yang diukur dari laporan keuangan perusahaan. Oleh karena itu perusahaan akan selalu mempublikasikan laporan keuangannya agar para calon investor dapat mengetahui bagaimana kinerja perusahaan, dan prospek perusahaan tersebut ke depan. Pembelian saham di pasar modal perlu meninjau harga saham yang ditawarkan oleh perusahaan. Investor dapat menilai tingkat kesesuain harga saham yang ditawarkan dengan nilai perusahaan tersebut.

Darmadji dan Fakhruddin (2006), menyatakan bahwa indeks harga saham adalah suatu indikator yang menunjukkan pergerak-an harga saham. Salah satu alat analisis dalam menilai harga saham adalah melalui analisis fundamental perusahaan melalui analisis rasio keuangannya.

Likuiditas perusahaan menunjukkan kemampuan perusahaan mendanai kegiatan operasional perusahaan dan membayar kewajiban jangka pendeknya. Menurut Munawir $(2004,72)$ rasio likuiditas, adalah rasio yang dimaksudkan untuk mengukur likuiditas perusahaan atau kemampuan suatu perusahaan memenuhi seluruh kewajiban finansial yang harus segera dibayar. Untuk dapat memenuhi segala kewajiban perusahaan pada waktu jatuh temponya. Perusahaan harus mempunyai aktiva lancar yang jumlahnya harus jauh lebih besar daripada kewajiban kewajiban yang harus segera dibayar terhadap hutang-hutang lancar.

Likuiditas perusahaan dapat diukur melalui rasio keuangan seperti: current ratio dan quick ratio (Hanafi, 2004, 37). Banyak penelitian menggunakan Current ratio sebagai rasio untuk menentukan nilai likuiditas dari perusahaan. Current ratio menunjukan perbandingan antara aktiva lancar dengan kewajiban (hutang) lancar. Semakin tinggi current ratio berarti semakin besar kemampuan perusahaan untuk memenuhi kewajiban finansial jangka pendek (Fauzan, Ittiba Unnurain dan Imron Rosyadi, 2004:17).

Profitabilitas adalah kemampuan peru- sahaan menghasilkan laba (profit). Laba inilah yang akan menjadi dasar pembagian dividen perusahaan, apakah dividen tunai ataupun di- viden saham. Suharli (2004) mengungkapkan laba diperoleh dari selisih antara harta masuk (pendapatan dan keuntungan) dan harta yang keluar (beban dan kerugian). Menurut Suharli 
(2004) mengemukakan bahwa untuk mengu- kur profitabilitas salah satunya menggunakan rasio Return on Asset (ROE). Menurut Hanafi $(2004,43)$ rasio yang sering digunakan untuk pengukur return (tingkat pengembalian) investasi yang diterima pemegang saham adalah Return on Asset (ROA).

Solvabilitas merupakan kemampuan perusahaan untuk memenuhi kewajiban jangka panjangnya (Ang,2005; Mahfoedz, 1994, dan Ediningsih,2004). Rasio-rasio solvabilitas antara lain adalah sebagai berikut:

a. Debt Ratio (DR) adalah perbandingan antara total hutang dengan total asset.

b. Debt to Equity Ratio (DER) yaitu perbandingan antara jumlah hutang lancar dan hutang jangka panjang terhadap modal sendiri.

c. Long Term Debt to Equity Ratio (LTDER) yaitu perbandingan antara hutang jangka panjang dengan modal sendiri.

Aktivitas menurut Ang (2005) adalah kemampuan perusahaan untuk memanfaatkan assetasset yang dimilikinya secara maksimal. untuk menghasilkan laba. Menurut Sutrisno (2001) rasio aktivitas adalah rasio yang mengukur seberapa besar efektivitas perusahaan dalam memanfaatkan sumber dananya. Rasio aktivitas dinyatakan sebagai perbandingan penjualan dengan berbagai elemen aktiva. Elemen aktiva sebagai pengguna dana seharusnya bisa dikendalikan agar bisa dimanfaatkan secara optimal. Semakin efektif dalam memanfaatkan dana semakin cepat perputaran dana tersebut, karena rasio aktivitas umumnya di- ukur dari perputaran masing-masing elemen aktiva. Salah satu ratio yang bisa digunakan untuk mengukur aktivitas adalah Total Asset Turn Over(TATO). TATO ini merupakan rasio yang menggambarkan perbandingan antara penjualan bersih dengan jumlah aktiva perusahaan.

Penelitian ini pernah dilakukan oleh peneliti sebelumnya dengan judul Pengaruh Rasio Keuangan Terhadap Harga Saham Perusahaan (Studi Kasus Pada Sektor Pertambangan dan Sektor Kimia), (Alan Andy Kusuma tahun 2008). Berdasarkan penelitian tersebut dapat ditarik kesimpulan :

a. Berdasarkan hasil penelitian yang dilakukan pada 10 perusahaan go public yang terdaftar di BEI periode 2005-2007, bahwa profitabilitas (ROA, ROE, NPM) dan EPS mempunyai pengaruh yang baik terhadap harga saham secara simultan. Dari pengaruh yang baik ini dapat diketahui bahwa manajemen perusahaan dapat menggunakan asset perusahaan dengan baik, peningkatan sales yang lebih besar dari peningkatan biaya, dan meningkatnya return yang akan diterima investor. Pengaruh ini dapat meningkat-kan harga saham dipasaran dan menarik investor untuk menginvestasikan modalnya di perusahaan tersebut.

b. Berdasarkan uji anova diketahui bahwa ROA, ROE, NPM, dan EPS secara bersama-sama berpengaruh secara signifikan terhadap harga saham pada tingkat kepercayaan 5\%. Dari hasil uji regresi berganda dengan taraf signifikan $\alpha-5 \%$ diketahui bahwa EPS, ROA, dan ROE memiliki nilai yang positif 6.268: 21.158 : 3.030 dan NPM memiliki nilai yang negative 21.431. hasil uji t secara parsial diketahui bahwa ROA, ROE, NPM dan EPS diperoleh $\mathrm{T}$ tabel sebesar 2.060. Dari hasil diatas, EPS berpengaruh terhadap harga saham sedangkan ROA, ROE, dan NPM tidak berpengaruh terhadap harga saham.

Penelitian ini dimaksudkan untuk menganalisis keterkaitan dan pengaruh variabel independen terhadap variabel dependen. Yaitu menganalisis pengaruh kinerja keuangan yang terdiri dari beberapa rasio keuangan yang berupa, , CR (Current Ratio), ROA (Return On Assets), DER (Debt to Equity Ratio), dan Total Asset Turn Over (TATO) terhadap harga saham pada bank yang terdaftar di Bursa Efek Indonesia.

Berdasarkan uraian di atas, maka per- masalahan dalam penelitian ini dirumuskan sebagai berikut: (1) Apakah CR, ROA, DER, dan TATO berpengaruh terhadap Harga Saham pada bank yang terdaftar di BEI?

Tujuan penelitian ini adalah untuk menge- tahui pengaruh CR,ROA,DER, dan TATO terhadap harga saham pada Bank yang terdaftar di BEI. Penelitian ini diharapkan dapat bermanfaat bagi berbagai pihak terkait, yaitu (1) memberikan kontribusi praktis bagi Investor didalam menginvestasikan uangnya pada entitas perusahaan yang dapat memberikan keuntungan yang optimal (2) bagi pelaku di pasar modal, penelitian ini diharapkan dapat memberikan informasi mengenai rasio-rasio keuangan yang bisa mempengaruhi Harga Saham, dan (3) penelitian ini diharapkan dapat memberikan kontribusi bagi pengembangan ilmu pengetahuan di masa yang akan datang. 


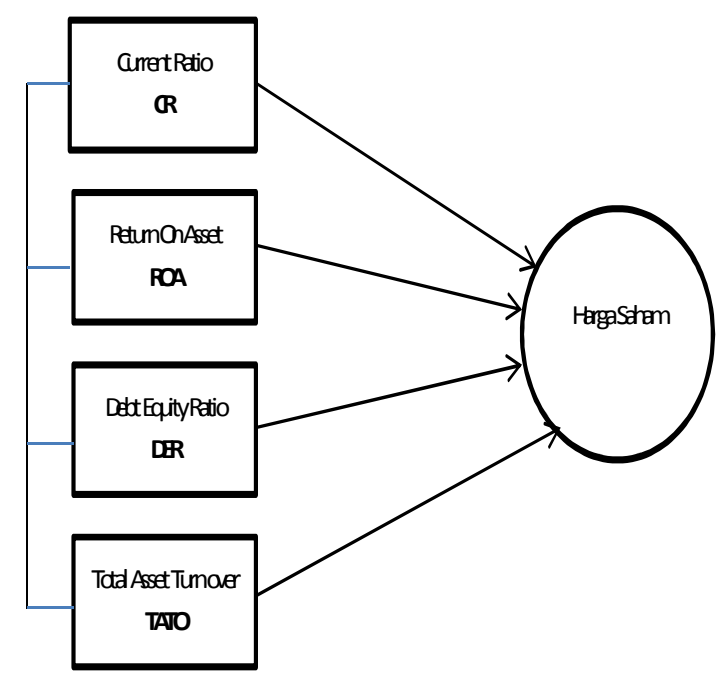

\section{METODE PENELITIAN}

Sumber data yang digunakan dalam penelitian ini adalah data sekunder berupa laporan keuangan yang diterbitkan Indonesian Capital Market Directory 2013. Data berupa laporan keuangan yang diperlukan mencakup data tahun 2008-2011. Adapun teknik pengumpulan data dilakukan dengan metode dokumentasi.

Populasi penelitian ini adalah meng-ambil sampel 7 bank terdaftar di Bursa Efek Indonesia dari Tahun 2008 sampai dengan tahun 2011.

Dalam penelitian ini perusahaan yang di-

gunakan sebagai sampel dipilih secara purposive sampling dari seluruh bank yang terdaftar di Bursa Efek Indonesia. Dengan metode ini sampel dipilih berdasarkan kriteria tertentu, yaitu sebagai berikut: (1) Bank yang terdaftar di BEI selama periode analisis. (2) Menerbitkan laporan keuangan per 31 Desember 2008-2011. (3) Memiliki data dan laporan keuangan yang berkaitan dengan pengukuran variabel penelitian.

\section{Definisi Operasional Variabel}

Untuk menjabarkan variabel-variabel yang sudah diklasifikasikan maka perlu definisi operasional dan pengukuran masing-ma- sing variabel sebagai berikut:

1. Rasio profitabilitas, merupakan rasio un- tuk mengukur kemampuan perusahaan menghasilkan keuntungan pada tingkat pen- jualan, assets, dan modal saham tertentu.

2. Rasio likuditas, merupakan rasio untuk mengukur kemampuan perusahaan untuk membayar kewajiban-kewajibannya yang segera harus dipenuhi.

3. Rasio solvabilitas, adalah rasio yang menggambarkan kemampuan perusahaan memenuhi kewajiban jangka panjangnya.

4. Rasio aktivitas, merupakan rasio untuk

mengukur sampai seberapa besar efekti- vitas perusahaan dalam mengerjakan sumbersumber dananya.

\section{Teknik Analisis Data dan Pengujian \\ Hipotesis}

Teknik analisis data menggunakan cross section berdasarkan laporan keuangan tahun 2008-2011 pada bank yang terdaftar di BEI.

Pengolahan data dilakukan dengan menggu- nakan program komputer SPSS Versi 19 for Windows. Analisis regresi linear berganda di- gunakan untuk menganalisis hipotesis dalam penelitian ini dan tingkat signifikansi yang digunakan sebesar 5\%. Model analisis regresi berganda dapat dirumuskan sebagai berikut:

$\mathrm{Y}=\mathrm{a}+\mathrm{b} 1 . \mathrm{X} 1+\mathrm{b} 2 . \mathrm{X} 2+\mathrm{b3} . \mathrm{X3}+\mathrm{b4} . \mathrm{X} 4+\mathrm{e}$

Keterangan:

$\mathrm{Y}=$ Price Share (PS)

$\mathrm{a}=$ Konstanta 
$\mathrm{X} 1=$ Current Ratio $(C R)$

$\mathrm{X} 2=$ Return on Asset (ROA)

$\mathrm{X} 3 \quad=$ Debt to Equity Ratio(DER)

TATO $=$ Total Asset Turn Over

b1-4 = Koefisien Regresi

$\beta_{0} \quad=$ Konstanta

e $\quad=$ Error

\section{Uji Hipotesis}

Uji t. Uji ini digunakan untuk mengetahui apa- kah variabel independen secara parsial mempengaruhi variabel dependen. Dengan tingkat sig- nifikan 5\%, maka kriteria ujinya adalah sebagai berikut:

Jika $\mathrm{t}$ tabel $\leq \mathrm{t}$ hitung $\leq \mathrm{t}$ tabel, jika $\mathrm{t}$ hitung atau $\mathrm{t}$ tabel $>+\mathrm{t}$ tabel, maka variabel independen tidak berpengaruh terhadap variabel dependen secara signifikan (Hipotesis alternatif ditolak)

Jika $\mathrm{t}$ hitung $<-\mathrm{t}$ tabel atau $\mathrm{t}$ hitung $>+\mathrm{t}$

tabel, maka variabel independen berpengaruh terhadap variabel dependen secara signifikan (hipotesis alternatif diterima).

Uji $F$. Uji ini digunakan untuk mengetahui pengaruh variabel independen terhadap variabel dependen secara bersama-sama. Dengan Alpha 5\%, kriteria setujunya sebagai berikut:

Jika $\mathrm{F}$ hitung $<\mathrm{F}$ tabel $($ sig $>0,05)$,

maka variabel independen secara bersama-sama tidak berpengaruh terhadap variabel dependen secara signifikan (hipotesis alternatif ditolak).

Jika $F$ hitung $>F$ tabel $($ sig $<0,05)$, maka variabel independen secara bersamasama ber pengaruh terhadap variabel dependen secara signifikan (hipotesis alternatif diterima).

Uji $R^{2}$. Analisis ini dilakukan untuk mengukur besarnya kemampuan menerangkan dari variabel independen terhadap variabel dependen dalam suatu model regresi. Nilai $R^{2}$ berkisar antara $0<R^{2}<1$ dan kecocokan model dikata kan lebih baik kalau nilai $R^{2}$ mendekati 1 , bila $R^{2}=1$, berarti persentase sumbangan variabel X1, X2, X3 dan X4 terhadap variabel dependen ada- lah $100 \%$. Apabila $R^{2}=0$, berarti variabel tidak dapat digunakan untuk membuat ramalan. (Gujarati, 2001:101).

\section{Uji Asumsi Klasik}

Pengujian asumsi klasik diperlukan untuk mengetahui apakah hasil estimasi regresi yang dilakukan benar-benar bebas dari adanya gejala heteroskedastisitas, gejala multikoli-nieritas, dan gejala autokorelasi.

\section{HASIL DAN PEMBAHASAN}

Berikut data Bank yang terdaftar di BEI yang digunakan sebagai sampel untuk penelitian

\begin{tabular}{|c|c|c|c|c|c|c|}
\hline \multirow{2}{*}{$\mathrm{NO}$} & \multirow{2}{*}{ NAMABANK } & \multirow{2}{*}{ KOEE } & \multicolumn{4}{|c|}{ QARENTRATIO(XI) } \\
\hline & & & 2008 & 2000 & 2010 & 2011 \\
\hline & PT.BANKRAKATINDONESA(PABSPO) TBK & EAP & 10939 & 10894 & 1095 & 1114 \\
\hline & PT. BANKEGARAINDONESA(PARBPQ) TBK & $\mathbb{B N}$ & 10630 & 177.59 & 117.54 & 11294 \\
\hline & PT. BANKTABUNGANNEGARA(PABSPQ) TBK & BBIN & 107.96 & 177.96 & 10805 & 107.12 \\
\hline & PT.BAKGENIRALASATIRK & ECA & 10928 & 10961 & 11058 & 11115 \\
\hline & P.BANKDANANONIBK & $\mathrm{EDMN}$ & 1095 & 117.05 & 11691 & 1200 \\
\hline & T.BANKNANDA (PABAR) TIBK & BMA & 107.91 & 1084 & 10896 & 11146 \\
\hline & BANHMPUNANSALAAA19O6TIBK & SLPA & 10924 & 1100 & 11168 & 10837 \\
\hline
\end{tabular}

\begin{tabular}{|c|c|c|c|c|c|c|}
\hline \multirow{2}{*}{$\mathrm{ND}$} & \multirow{2}{*}{ NAMABANK } & & \multicolumn{4}{|c|}{ REIUNANASSEI(X) } \\
\hline & & & 2008 & 200 & 200 & 2011 \\
\hline & 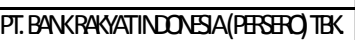 & Ex & 359 & 31 & $3 \oplus$ & \\
\hline & PT. BANKNEGAPAINDONEAA(PARSPO) TRK & BN & 096 & 151 & 22 & 24 \\
\hline & PT. BANKTABUNGANNEGARA(PABSEO) TIEK & BIIN & 12 & 12 & 183 & 171 \\
\hline & PT.BANKG NIRALASATBK & BCA & 314 & 37 & 328 & 357 \\
\hline & PI.BAKDDNANAN & BDMN & $250 \mid$ & 240 & 339 & 32 \\
\hline
\end{tabular}




\begin{tabular}{|c|c|c|c|c|c|c|}
\hline \multirow{2}{*}{$\mathrm{NO}$} & \multirow{2}{*}{ NAMABANK } & \multirow{2}{*}{$\mathrm{KOOE}$} & \multicolumn{4}{|c|}{ DBITOEQ IYRATI(X) } \\
\hline & & & 2008 & 200 & 200 & $\mathbf{2 0 1 1}$ \\
\hline & PT. BANKRAKYATINDONESA(PEASEO) TRK & EPA & 1001 & 106 & 1002 & 84 \\
\hline & PT. BANKNEGARAINDCNESA(PARSPO) TRK & BNN & 1207 & 108 & 650 & 690 \\
\hline & SP. BANKTABUNGANNEGARA(PERERQ) TIEK & EBIN & 971 & 971 & 961 & 1171 \\
\hline & PI. BANKG ENIRALASATBK & EBCA & 95 & 914 & 851 & 809 \\
\hline & PT.BANKDANAMONIBK & BDMN & 909 & 523 & 540 & 449 \\
\hline & PI.BAKKNANDR (PAESPO) TBK & BMA & 105 & 1023 & 981 & 7.81 \\
\hline & BANKHMPUNANSALARA1966IEK & SLRA & 886 & 848 & 7.5 & $9 \sqrt{3}$ \\
\hline
\end{tabular}

\begin{tabular}{|c|c|c|c|c|c|c|}
\hline \multirow{2}{*}{$\mathrm{ND}$} & \multirow{2}{*}{ NAMABANK } & \multirow{2}{*}{ KOOE } & \multicolumn{4}{|c|}{ TOTALASSETTUROAT(XA) } \\
\hline & & & 2008 & 200 & 200 & $\mathbf{2 0 1 1}$ \\
\hline & PT. BAKRAKYATINDONESA(PEASPO) TEK & EPr & 1142 & 105 & 1104 & $\overline{1025}$ \\
\hline & PT. BANKNEGARAINDCNEIA(PARSER) TEK & ENN & 824 & 855 & 7.58 & 692 \\
\hline & PT. BANKTABUNGANNEGARA(PERERO) TIKK & BIN & 979 & 979 & 950 & 848 \\
\hline & PI. BANKGENIRALASATBK & EBCA & 7.86 & 812 & 637 & 643 \\
\hline & PT.BANKDANAMONIEK & EDMN & $150 B$ & 17.92 & 1220 & $11 \%$ \\
\hline & SP. BANKMANDR (PERSRO) TBK & BMA & 7.6 & 826 & 7.54 & 684 \\
\hline & BANKHMPUNANSALDARA1906IRK & SLRA & 1532 & 142 & 1394 & 1151 \\
\hline
\end{tabular}

\begin{tabular}{|c|c|c|c|c|c|c|}
\hline \multirow{2}{*}{$\mathrm{ND}$} & \multirow{2}{*}{ NAMABAK } & \multirow{2}{*}{ KOOE } & \multicolumn{4}{|c|}{ HARGASAHAM } \\
\hline & & & 2008 & 200 & 200 & 2011 \\
\hline & PT. BANKRAKYATINDONESA(PARSEO) TRK & EPA & 4550 & 3,850 & 5,2500 & 67500 \\
\hline & PT. BANKNEGARAINDCNESA(PARSER) TEK & ENN & $\circledast 0$ & 1,810 & $3,8 / 50$ & 3,800 \\
\hline & SP. BANKTABUNGANNEGARA(PERERQ) TBK & BIIN & 887.0 & 8400 & 1,6400 & 1,160 \\
\hline & TP. BANKGENIRALASATBK & EBCA & 3,2500 & 48500 & 64000 & 8000 \\
\hline & PT.BANKDANAMONIEK & $\mathrm{BDMN}$ & 3,100 & 44180 & 5,5550 & 4100 \\
\hline & SP. BANKMANDR (PERERO) TBK & BMT & 2,050 & 4220 & 63920 & 67500 \\
\hline & BANKHMPUNANSALARA1906IBK & SLRA & 500 & 2800 & 2900 & 200 \\
\hline
\end{tabular}

Dengan menggunakan aplikasi SPSS didapat hasil uji T sebagai berikut:

\begin{tabular}{|c|c|c|c|c|c|c|}
\hline \multicolumn{7}{|c|}{ Coefficientsa } \\
\hline \multirow[b]{2}{*}{ Mbdel } & & \multicolumn{2}{|c|}{$\begin{array}{l}\text { Unstandardized } \\
\text { Coefficients }\end{array}$} & $\begin{array}{c}\text { Standaralz } \\
\text { ed } \\
\text { Coefficient } \\
\text { s }\end{array}$ & \multirow[b]{2}{*}{$\mathrm{t}$} & \multirow[b]{2}{*}{ Sig. } \\
\hline & & $\mathrm{B}$ & Std. Error & Beta & & \\
\hline \multirow[t]{5}{*}{1} & (Constant) & -850.357 & 14068.075 & & -.060 & .952 \\
\hline & CR & 48.183 & 114.619 & .071 & .420 & .678 \\
\hline & ROA & 2004.074 & 324.034 & .680 & 6.185 & .000 \\
\hline & DER & -290.325 & 214.920 & -.232 & -1.351 & .190 \\
\hline & TATO & -369.428 & 88.323 & -.472 & -4.183 & .000 \\
\hline
\end{tabular}

Dari data yang ada diketahui persamaan yang terbentuk adalah sebagai berikut:

$$
Y=-850,357+48,183 \times 1+2004,074 \times 2-290,325 X 3-369,428
$$

Dimana:

$\mathrm{Y}=$ Harga Saham (Price Share/PS)

$\mathrm{X} 1=$ Current Ratio $(\mathrm{CR})$

$\mathrm{X} 2=$ Return On Asset (ROA)

$\mathrm{X} 3=$ Debt to Equity Ratio (DER)

X4=Total Asset Turn Over (TATO)

Dari data ini pula dapat dijelaskan hal-hal sebagai berikut:

1. Konstanta-850,357 menunjukkan apabila variabel CR,ROA, DER. Dan TATO adalah konstan maka nilai Harga Saham (Price Share) adalah negatif. 
2. Koefisien Current Ratio sebesar $+48,183$ menunjukkan bahwa Koefisien ini memiliki pengaruh searah dengan nilai Harga Saham yaitu apabila Current Ratio (CR) naik maka Harga Saham juga naik. Karena Variabel CR memiliki signifikasi sebesar 0,678 $(>0,05)$ berarti CR tidak berpengaruh secara signifikan terhadap Harga Saham.

3. Koefesien Return On Asset sebesar $+2004,074$ menunjukkan bahwa koefisien ini memiliki pengaruh searah dengan nilai Harga Saham yaitu apabila ROA naik maka Harga Saham juga naik. Karena Variabel ROA memiliki signifikasi sebesar $0,000(<0,05)$ maka berarti ROA memiliki pengaruh yang signifikan terhadap Harga Saham.

4. Koefisien Debt to Equity Ratio (DER) sebesar -290,325 menunjukkan bahawa koefisien ini memiliki pengaruh berlawanan terhadap Harga Saham, maka Koefisien ini tidak dapat diinter-pretasikan. Signifikasi DER sebesar 0,190(>0,05) maka berarti DER tidak memiliki pengaruh yang signifikan terhadap Harga Saham.

5. Koefisien TATO sebesar $-369,428$ maka koefisin ini memiliki pengaruh yang berlawanan dengan Harga Saham, maka koefisien ini tidak dapat diinterpretasikan. Signifikasi TATO sebesar $0,000(<0,05)$ maka berarti TATO memiliki pengaruh yang signifikan terhadap harga saham.

Dari Output SPSS didapat hasil $\mathrm{R}^{2}$ sebagai berikut:

\begin{tabular}{|l|r|r|r|r|}
\hline \multicolumn{5}{|c|}{ Model Summaryb } \\
\hline Model & \multicolumn{1}{|c|}{ R } & R Square & $\begin{array}{l}\text { Adjusted } \\
\text { R Square }\end{array}$ & $\begin{array}{r}\text { Std. Error of } \\
\text { the Estimate }\end{array}$ \\
\hline 1 & .873 & .762 & .721 & 1246.51754 \\
\hline
\end{tabular}

Dari data ini diketahui bahwa CR.ROA,DER, dan TATO secara bersama-sama dapat menerangkan variabel Harga Saham sebesar 0,762 atau 76,2\%, sedangkan sisanya $23,7 \%$ diterangkan oleh Variabel lainnya.

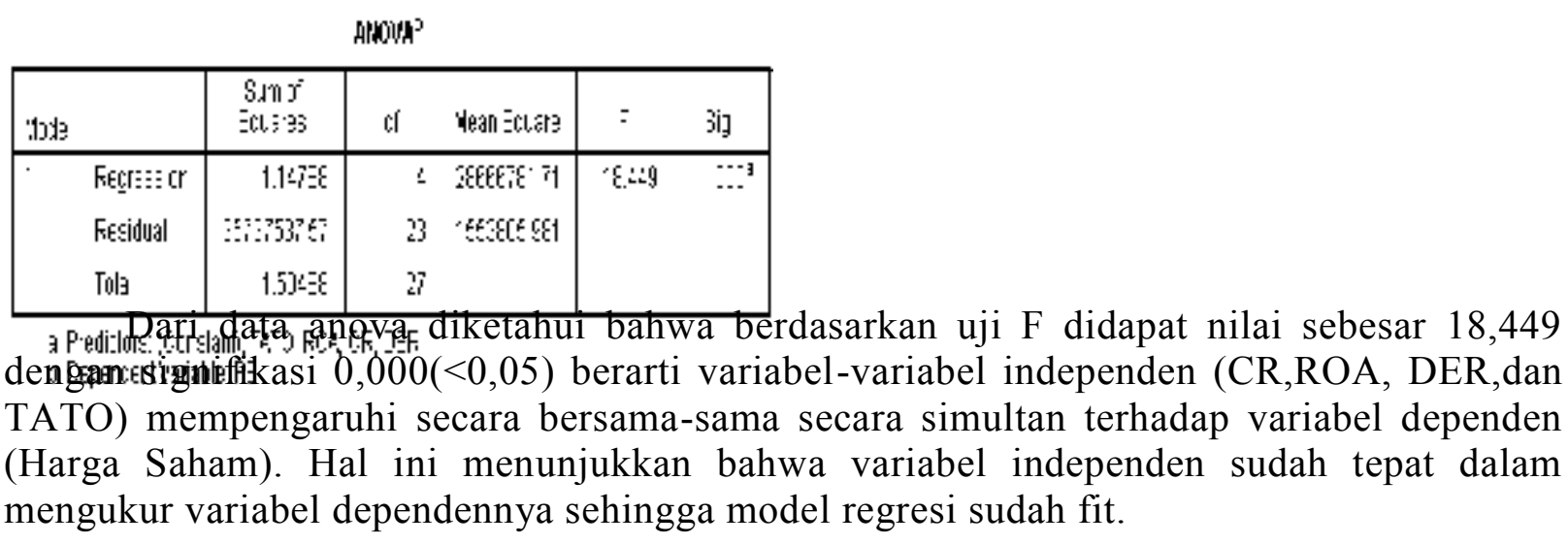

\section{Pengujian Asumsi Klasik}

Model yang digunakan dalam penelitian ini adalah linear regresi berganda. Agar hasil regresi sahih maka harus terpenuhi asumsi klasik, yaitu Normalitas, Autokorelasi, multikolinieritas, heterodas-tisitas.

\section{(1) Uji Normalitas}

Hasil dari analisi ini terhadap asumsi normalitas dikatakan baik apabila semua data tersebar secara merata di sekitar garis horisontal dan mengikuti garis horisontal.

Untuk penelitian ini didapat hasil uji normalitas sebagai berikut:

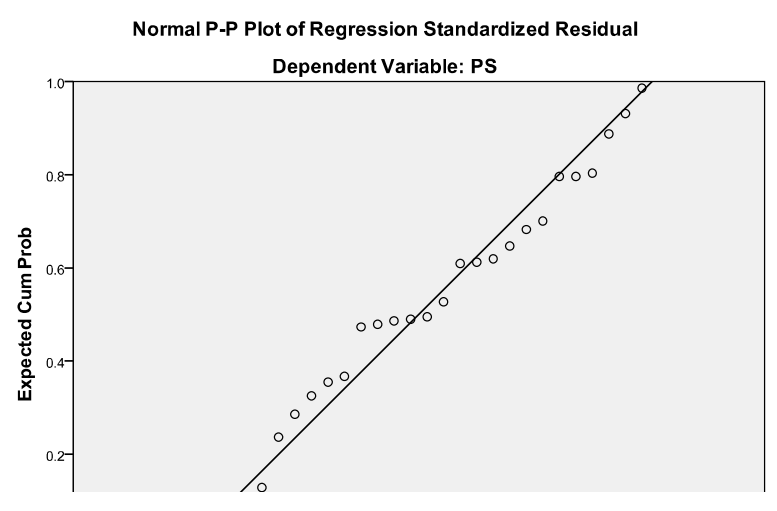


Berdasarkan gambar yang ada diketahui data tersebar secara merata di sekitar garis horisontal dan mengikuti garis horisontal(memenuhi uji Normalitas).

\section{(2) Uji Multikolinieritas}

Multikolinieritas terindikasi apabila terdapat hubungan linier diantara variabel independen yang digunakan dalam model. Metode untuk adanya multikolinieritas dilihat dari nilai tolerance value atau Variance Inflation Factor (VIF).

Hasil yang diperoleh dari Uji Multikolinieritas dengan menggunakan SPSS dapat dilihat pada tabel berikut:

\begin{tabular}{|c|c|c|c|}
\hline \multicolumn{3}{|c|}{ Coefficientsa } & \multirow{3}{*}{ Kesimpulan } \\
\hline \multirow[b]{2}{*}{ Mbdel } & \multicolumn{2}{|c|}{ Collinearity Statistics } & \\
\hline & Toleranœ & UF & \\
\hline (Constant) & & & \\
\hline CR & .359 & 2.784 & Bebas Multikolinieritas \\
\hline ROA & .855 & 1.170 & Bebas Miltikolinieritas \\
\hline $\mathrm{DER}$ & .349 & 2.867 & Bebas Multikolinieritas \\
\hline TATO & .811 & 1.234 & Bebas Multikolinieritas \\
\hline
\end{tabular}

Hasil dari analisis menunjukkan bahwa nilai VIF variabel dibawah nilai 10 dan tolerance value diatas 0,10 sehingga dapat disimpulkan tidak terjadi multikolinieritas dalam model regresi.

\section{(3) Uji Heterodastisitas}

Uji heterodastisitas bertujuan untuk menguji apakah dalam model regresi terjadi ketidaksamaan varians dari residual suatu pengamatan ke pengamat-an yang lain. Pengujian ini dilakukan untuk melihat apakah variabel pengganggu mempunyai varians yang sama atau tidak. Heterokedastisitas mempunyai suatu keadaan bahwa varian dari residual satu pengamatan ke pengamatan lainnya berbeda. Heterokedastisitas bertentangan dengan salah satu asumsi dasar regresi linear, yaitu bahwa variasi residual sama untuk semua pengamatan atau disebut homokedastisitas (Gujarati dalam Elmasari, 2010:53). Untuk mendeteksi ada atau tidaknya heteroskedastisitas yaitu dengan melihat grafik plot antara nilai prediksi variabel (dependen) yaitu ZPRED dengan residualnya SRESID. Deteksi ada atau tidaknya heteroskedastisitas dapat dilakukan dengan melihat ada tidaknya pola tertentu pada grafik scatterplot antara SPRESID dan ZPRED dimana sumbu $\mathrm{Y}$ adalah $\mathrm{Y}$ yang telah diperidiksi, sumbu $\mathrm{X}$ adalah residual (Yprediksi - Y sesungguhnya) yang distudentized.

Dasar analisisnya adalah sebagai berikut:

a. Jika ada pola tertentu, seperti titik-titik yang ada membentuk pola tertentu yang teratur (bergelombang, melebar, kemudian menyempit) maka mengindikasikan telah terjadi hete-roskedastisitas.

b. Jika ada pola yang jelas, serta titik-titik menyebar di atas dan dibawah angka 0 pada sumbu Y, maka tidak terjadi heteroskedastisitas.

Berdasarkan hasil pengujian Heteroskedastisitas dengan mengguna-kan SPSS didapat hasil berikut:

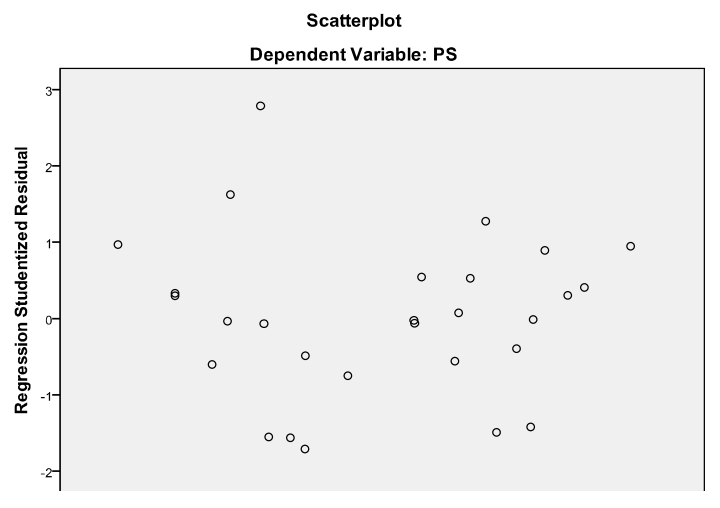


Dari gambar diatas terlihat bahwa data tersebar tidak beraturan diantara sumbu $\mathrm{Y}$ baik diatas nilai 0 maupun dibawah nilai ), maka dikatakan tidak terjadi heterokedastisitas.

Uji autokorelasi merupakan pengujian asumsi dalam regresi diaman variabel dependen tidak berkorelasi dengan dirinya sendiri. Maksud korelasi dengan diri sendiri adalah bahwa nilai dari variabel dependen tidak berhubungan dengan nilai variabel itu sendiri, baik nilai variabel sebelumnya atau nilai periode sesudahnya (Santosa \& Ashari, 2009:240).Untuk Uji Autokorelasi digunakan Durbin Watson, Hasil output SPSS atas Durbin Watson adalah sebagai berikut:

\begin{tabular}{|l|r|r|r|r|r|r|}
\hline Mbdel & $\begin{array}{r}\text { Durbin- } \\
\text { Watson }\end{array}$ & \multicolumn{1}{c|}{$\mathrm{dl}$} & $\mathrm{du}$ & \multicolumn{1}{c|}{ 4-dl } & 4-du & keterangan \\
\hline Regresi & 2.658 & 1.104 & 1.747 & 2.896 & 2.253 & NoDecision \\
\hline
\end{tabular}

Karena Uji autokorelasi dengan menggunakan Durbin Watson dihasilkan no decision, maka dilakukan pengujian lanjutan dengan menggunakan uji run test dan didapat hasil sebagai berikut:

Runs Test

\begin{tabular}{|l|r|}
\hline & $\begin{array}{c}\text { Unstandardiz } \\
\text { ed Predicted } \\
\text { Value }\end{array}$ \\
\hline Test Value $^{\mathrm{a}}$ & 3861.18507 \\
Cases < Test Value & 14 \\
Cases >= Test Value & 14 \\
Total Cases & 28 \\
Number of Runs & 16 \\
Z & .193 \\
Asymp. Sig. (2-tailed) & .847 \\
\hline
\end{tabular}

a. Median

Dari hasil Uji run test didapat hasil Asmp. Sig. (2-tailed) 0,8647 nilai ini lebih besar dari $\alpha=5 \%$, maka dikatakan data cukup random sehingga tidak terjadi autokorelasi.

Berdasarkan keseluruhan uji klasik yang telah dilakukan (normalitas, autokorelasi, multikorelasi, heteroskedastisitas) diperoleh hasil bahwa dalam model yang digunakan sudah tidak terjadi penyimpangan asumsi klasik, artinya model regresi pada penelitian dapat digunakan sebagai dasar analisis.

\section{KESIMPULAN}

Berdasarkan hasil penelitian dan pembahasan yang telah dilakukan, diperoleh kesimpulan sebagai berikut:

1. Hasil uji t menjelaskan bahwa variabel ROA mempengaruhi variabel Harga Saham secara signifikan dan positif, sedangkan Variabel TATO mempengaruhi variabel Harga Saham secara signifikan dan negatif. Dari Penelitian ini diketahui pengaruh dari variabel-variabel independen (CR,ROA, DER, dan TATO) terhadap Variabel dependen (Harga Saham), hanya kedua variabel ROA dan TATO saja yang berpengaruh secara signifikan, sedangkan dua variabel lainnya yaitu CR dan DER tidak berpengaruh secara signifikan terhadap variabel Harga Saham.

2. Hasil dari uji asumsi klasik (normalitas, autokorelasi, multikolinieritas, heteroske-dastisitas) diperoleh hasil analisis bahwa dalam model yang digunakan sudah tidak terjadi penyimpangan asumsi klasik, artinya model regresi pada penelitian dapat digunakan sebagai dasar analisis.

3. Penelitian ini mempunyai keterbatasan dengan variabel yang digunakan yaitu hanya 4 variabel independen (CR,ROA,DER,dan TATO) dan 1 variabel dependen (Harga Saham). Penelitian ini juga memiliki keterbatasan dalam populasi yang digunakan yaitu hanya 11 
sampel bank dari BEI untuk data 2008-2011 yang ada di ICMD 2013.

\section{SARAN}

Berdasarkan hasil penelitian dan pembahasan yang telah dilakukan, diperoleh kesimpulan sebagai berikut:

1. Peneliti selanjutnya dapat lebih memperlama jangka waktu penelitian dan memperbanyak data sampel yang digunakan supaya didapat data dan hasil penelitian yang lebih memuaskan.

2. Peneliti selanjutnya dapat pula memperluas bidang penelitian yang dilakukan, tidak hanya bank tapi juga bidang-bidang lain seperti manufaktur, food and beverage, dan bidang-bidang lainnya yang terdaftar di BEI.

\section{DAFTAR PUSTAKA}

Asri, Jatnika Dwi.2011."Pengaruh Earning Per Share (EPS) dan Pertumbuhan Asset Terhadap Harga Saham (Studi Kasus pada Perusahaan Sektor Pertanian yang Listing Di Bursa Efek Indonesia Tahun 2003.Dalam Jurnal Ekono Insentif Kopwil4. Dalam Journal Econo Insentif, Volume 5 No.1. Hal1-7. Institut Pemerintah Dalam Negeri

Fakhruddin.2006.Pasar Modal Di Indonesia Pendekatan Tanya Jawab (Edisi kedua). Jakarta: Salemba Empat

Ghozali, Imam. 2011. Aplikasi Analisis Multivariate Dengan Program IBM SPSS 19. Semarang: Universitas Diponegoro

Hanafi, Mamduh, M., 2004. Manajemen Ke- uangan, Edisi 2004/2005, Badan Pener- bit Fakultas Ekonomi-UGM, Yogyakar- ta.

Husnan, Suad, 2000. Manajemen Keuangan, Teori dan Penerapan, Edisi Ke Tiga, BPFE Universitas Gadjah Mada, Yogya- karta.

Ikatan Akuntan Indonesia, 2007, Standar Akuntansi Keuangan per 1 September 2007, Salemba Empat, Jakarta.

Hadianto,Bram.2008."Pengaruh Earning Per Share (EPS) dan Price Earning Ratio (PER) Tarhadap Harga Saham Sektor Perdagangan Besar dan Ritel Pada Periode 2000-2005 Di Bursa Efek Indonesia”.Dalam Jurnal Ilmiah Akuntansi,Volume 7 No.2.Hal 162 173

Murhadi, Werner. Pengujian Asumsi Regresi. (2011). Diakses: 30 Mei 2013. http://wernermurhadi.wordpress.com/2011/07/18/asumsi-klasik/

Munawir. S., 2004. Analisa Laporan Keuangan, Liberty, Yogjakarta.

Prihadi Utomo, Yuni. (2007). Eksplorasi Data dan Analisis Regresi dengan SPSS. Surakarta: Muhammadiyah University Pess.

Riyanto, Bambang, 2000. Dasar-dasar Pembelanjaan Perusahaan, Badan Penerbit Fakultas Ekonomi-UGM, Yogjakarta.

Suharli, 2004. Memprediksi Tingkat Pengem- balian Investasi pada Equity Securities melalui Rasio Profitabilitas, Liquiditas dan Hutang Perusahaan Publik di Ja-karta, Thesis, Universitas Diponegoro, Semarang.

Sutrisno, 2001. Manajemen Keuangan, Teori, Konsep dan Aplikasi, Ekonisia, Yogja- karta.

Soetjipto, Kery, 2002. Pengaruh Pengumu- man Dividen terhadap Return Saham di Bursa Efek Jakarta. Tesis Magister Ma- nagement Universitas Gadjah Mada, Yogjakarta.

Tandjeng, Jerry Mustafa, 2007. Pengaruh Rasio Keuangan terhadap Dividend Pay out Ratio pada Perusahaan-Perusahaan Publik yang Tergabung dalam Index $L Q-$ 45. Tesis, Program Magister Manajemen Universitas Lambung Mangkurat, Ban- jarmasin.

Warsono, 2003. Manajemen Keuangan Peru- sahaan, Bayumedia Publishing, Jakarta.

Weston, J. Fred and Thomas E. Copeland, 2001. Manajemen Keuangan, Edisi Kesembilan, Terjemahan Penerbit. Bina- rupa Aksara, Jakarta. 